\title{
Study of Bagging Application in the Safe-Level Smote Method in Handling Unbalanced Classification
}

\author{
Kajian Penerapan Bagging pada Metode Safe-Level Smote dalam \\ Penanganan Klasifikasi Kelas Tidak Seimbang
}

\author{
Qorry Meidianingsih ${ }^{1 \ddagger}$ and Debby Agustine ${ }^{2}$
}

\author{
${ }^{1}$ Study Program of Mathematics Education, State University of Jakarta (UNJ), Indonesia \\ ${ }^{2}$ Study Program of Mathematics, State University of Jakarta (UNJ), Indonesia \\ ${ }^{\ddagger}$ corresponding author: qorrymeidianingsih@unj.ac.id
}

Copyright (c) 2021 Qorry Meidianingsih and Debby Agustine. This is an open-access article distributed under the Creative Commons Attribution License, which permits unrestricted use, distribution, and reproduction in any medium, provided the original work is properly cited.

\begin{abstract}
The problems of imbalanced class classification have been found in many real applications. It has potential to make the minority class instances tend to be classified into the majority class. This study examined the performance of bagging method's application in safe-level SMOTE based on Support Vector Machine classifier. The data used consisted of three types based on the proportion of observations in the majority and minority classes. Each type of data has three variables, two independent variables and one variable dependent. The observations of independent variables were generated based on multivariate normal distribution, while dependent variables are binary. The results showed that the classifier has a high accuracy and sensitivity for all types of data for both in the imbalanced class and the balanced class (obtained by safe-level SMOTE and safe-level SMOTEBagging). Nevertheless, specificity was the main measure in assessing the performance of the classifier because it provides accuracy in classifying the minority class observations. The specificity increased when the number of observations between the two classes were approximately balance due to the implementation of safe-level SMOTE. The best performance of the Support Vector Machine in predicting minority class observations was achieved when bagging were applied in safe-level SMOTE. The specificity rate for all types of data were 77.93 percent, 78.46 percent, and 85.69 percent, respectively.
\end{abstract}

Keywords: bagging, imbalanced class, smote, safe-level smote, support vector machine.

\footnotetext{
* Received: Nov 2020; Reviewed: Jan 2021; Published: Mar 2021
} 


\section{Pendahuluan}

Permasalahan klasifikasi menjadi kajian yang dipelajari oleh komunitas data mining dan machine learning pada berbagai bidang. Klasifikasi merupakan topik yang beragam dan algoritme yang digunakan sangat bergantung kepada domain data dan skenario masalah yang dihadapi. Oleh karena itu, masalah yang ditemui mungkin lebih beragam (Aggarwa, 2015). Salah satu permasalahan yang terjadi dalam klasifikasi dan kini banyak dipelajari oleh peneliti yaitu terkait dengan kelas tidak seimbang (Japkowicz, 2000). Beberapa penelitian telah dilakukan dalam mengembangkan teknik untuk kasus data dengan kelas tidak seimbang. (He \& Garcia, 2009) serta Galar et al. (2011) menjelaskan beberapa metode yang dapat digunakan untuk mengatasi masalah data tidak seimbang. (Hanifah et al., 2015) memprediksi calon debitur kredit tanpa agunan yang berpotensi gagal dalam memenuhi kewajibannya kepada bank (kredit macet). Hasil penelitian menunjukan bahwa jika metode klasifikasi regresi logistik diterapkan pada data tersebut, maka tingkat akurasi yang diperoleh sebesar 86 persen dengan tingkat kepekaannya 0 persen atau seluruh nasabah kredit macet diklasifikasikan ke dalam status kredit lancar. Metode klasifikasi standar tidak dapat menghasilkan keputusan akhir yang tepat ketika kondisi kelas tidak seimbang. Hal ini disebabkan salah satu kelas memiliki contoh yang jauh lebih banyak, disebut kelas mayoritas, sehingga hasil klasifikasi akan bias atau menghasilkan kesalahan klasifikasi.

Pendekatan solusi yang dapat dilakukan dalam menangani permasalahan data dengan kelas tidak seimbang terbagi menjadi dua jenis. Pendekatan pertama diterapkan pada level data atau dikenal dengan data preprocessing, yaitu membuat sebaran kelas menjadi seimbang mungkin. Setelah semua kelas memiliki jumlah amatan yang lebih seimbang, maka model klasifikasi standar dapat diterapkan. Pendekatan lainnya dapat dilakukan dengan memodifikasi algoritme pada metode klasifikasi standar sehingga peneliti tidak perlu merubah sebaran kelas yang dimiliki. Modifikasi tersebut dilakukan untuk mengenali contoh di kelas minoritas (Mahdizadeh \& Eftekhari, 2013). Kekurangan dari pendekatan ini yaitu dalam menerapkannya bergantung dengan jenis metode klasifikasi dan kesulitan dalam menanganinya (Sahare \& Gupta, 2012) . Solusi pada level data lebih mudah digunakan dibandingkan dengan pendekatan level algoritme karena gugus data diperbaiki dahulu sebelum diterapkan metode klasifikasi (Chawla, 2009). Selain itu, pendekatan pada level data tidak tergantung pada metode klasifikasi yang dipilih sehingga dapat diterapkan pada semua gugus data untuk melatih metode klasifikasi yang berbeda (Hussein et al., 2019).

Data preprocessing mencakup dua pilihan solusi, yaitu mengeliminasi contoh pada kelas mayoritas (undersampling) atau menambah contoh pada kelas minoritas (oversampling). (Akbani et al., 2004) mengungkapkan bahwa saat metode undersampling dilakukan pada kelas mayoritas, contoh pada kelas mayoritas tersebut tidak lagi bersifat acak. Teknik oversampling dipilih pada penelitian ini karena undersampling memungkinkan untuk membuang data amatan yang valid dan memberikan informasi penting. Synthetic Minority Over-sampling Technique (SMOTE) merupakan salah satu teknik oversampling yang popular, diperkenalkan oleh (Chawla et al., 2002). SMOTE membangkitkan data sintetis berdasarkan jumlah tetangga terdekat nya ( $k$-tetangga terdekat). SMOTE menarik banyak perhatian 
peneliti sehingga metode tersebut dijadikan sebagai dasar dari perkembangan metode oversampling lainnya. Borderline SMOTE diusulkan oleh (Han et al., 2005) sebagai teknik oversampling yang dapat menyempurnakan SMOTE. Metode ini hanya fokus pada amatan kelas minoritas yang berada di borderline atau batas antara kelas mayoritas dan minoritas. Setelah itu, muncul safe-level SMOTE pada tahun 2009 yang diperkenalkan oleh (Bunkhumpornpat et al., 2009). Metode safe-level SMOTE memiliki beberapa kriteria untuk menentukan apakah data sintetis dapat dibangkitkan atau tidak. Kriteria tersebut dinamakan safe-level rasio. Ketika amatan kelas minoritas dan tetangga terdekatnya berada di wilayah yang aman, maka data sintetis dapat dibangkitkan.

Teknik oversampling tidak hanya dapat diterapkan pada pengklasifikasi (classifier) tunggal, tetapi juga pada beberapa pengklasifikasi. Beberapa classifier tunggal dikombinasikan dan hasil prediksi dari masing-masing pengklasifikasi digabungkan melalui proses voting. Hal tersebut merupakan konsep dari metode ensemble. Bagging merupakan salah satu metode ensemble yang menggunakan teknik bootstrap dalam menghasilkan gugus data baru untuk membuat pengklasifikasi dalam banyak versi. Jika dibandingkan dengan pengklasifikasi tunggal, hasil prediksi bagging hampir selalu lebih akurat (Zhou, 2012). Berdasarkan hal tersebut, penelitian ini akan mengkaji performa penerapan metode bagging pada algoritme safe-level SMOTE berdasarkan metode klasifikasi Support Vector Machine. Kajian tersebut dilakukan dengan membandingkan performa hasil metode klasifikasi pada berbagai data simulasi yang dibedakan bedasarkan proporsi ketidakseimbangan kelas. Perbandingan kinerja metode klasifikasi dilakukan berdasarkan tiga kriteria, yaitu akurasi, sensitifitas, dan spesifisitas.

\section{Metodologi}

\subsection{Bahan dan Data}

Data yang digunakan pada penelitian ini merupakan data simulasi. Setiap data simulasi memiliki tiga peubah, yaitu dua peubah bebas $\left(X_{1}\right.$ dan $\left.X_{2}\right)$ yang bersifat numerik dan satu peubah tidak bebas $(Y)$ yang bersifat kategorik atau dalam hal ini sebagai kelasnya. Amatan pada peubah bebas dibangun berdasarkan sebaran normal ganda, sedangkan amatan pada peubah tidak bebas bersifat bernilai 0 dan 1 yang dibangkitkan secara acak sesuai dengan proporsi amatan yang disajikan pada Tabel 1 .

Tabel 1: Proporsi amatan kelas mayoritas dan minoritas

\begin{tabular}{ccc}
\hline Data & Kelas Mayoritas & Kelas Minoritas \\
\hline Data 1 & $95 \%$ & $5 \%$ \\
Data 2 & $90 \%$ & $10 \%$ \\
Data 3 & $85 \%$ & $15 \%$ \\
\hline
\end{tabular}

\subsection{Ukuran Kinerja Metode Klasifikasi}

Perbandingan kinerja metode klasifikasi dilakukan berdasarkan tiga kriteria, yaitu akurasi, sensitifitas, dan spesifisitas. Ketiga ukuran tersebut dapat diperoleh melalui confusion matrix, seperti disajikan pada Tabel 2. 
Tabel 2: Confusion matrix

\begin{tabular}{cccc}
\hline & \multicolumn{2}{c}{ Hasil Prediksi } \\
\cline { 2 - 4 } Keadaan & Positif & Negatif \\
\cline { 2 - 4 } sesungguhnya & Positif & True Positive (TP) & False Negatif (FN) \\
\hline
\end{tabular}

dengan

$$
\begin{aligned}
& \text { Akurasi }=\frac{\mathrm{TP}+\mathrm{TN}}{\mathrm{TP}+\mathrm{TN}+\mathrm{FP}+\mathrm{FN}} \\
& \text { Sensitifitas }=\frac{\mathrm{TP}}{\mathrm{TP}+\mathrm{FN}} \\
& \text { Spesifisitas }=\frac{\mathrm{TN}}{\mathrm{TN}+\mathrm{FP}}
\end{aligned}
$$

Akurasi memberikan gambaran mengenai tingkat ketepatan metode klasifikasi secara keseluruhan, artinya akurasi menjawab pertanyaan berapa persen amatan yang diklasifikasikan secara benar ke dalam kelas mayoritas dan minoritas dari semua amatan. Sensitifitas mengukur persentase amatan kelas mayoritas yang diklasifikasikan dengan benar dari seluruh amatan yang sesungguhnya berasal dari kelas mayoritas, sedangkan spesifisitas mengukur hal yang tidak diukur oleh sensitifitas sehingga lebih fokus kepada ketepatan dalam memprediksi amatan kelas minoritas.

\subsection{Bagging}

Bagging merupakan singkatan dari bootstrap aggregating yang diperkenalkan oleh Breiman pada tahun 1996. Metode bagging memiliki dua tahapan dalam analisisnya, yaitu bootstrap atau pengambilan contoh dari data contoh (resampling) dan aggregating atau menggabungkan banyak nilai dugaan menjadi satu nilai dugaan (Sartono \& Syafitri, 2010). SMOTEBagging merupakan kombinasi antara metode Synthetic Minority Oversampling Technique (SMOTE) dan algoritme bagging. SMOTEBagging menerapkan algoritme SMOTE sebelum pemodelan klasifikasi pada setiap gugus data latih (sebanyak $k$ buah) yang diperoleh melalui proses bootstrap. Selanjutnya setiap data latih tersebut akan diterapkan metode klasifikasi dan dilakukan proses aggregating atau pemilihan suara terbanyak untuk hasil prediksi gabungannya. Berdasarkan prinsip SMOTEBagging tersebut, maka akan diterapkan pula teknik bagging pada algoritme safe-level SMOTE dengan prosedur pembangkitan data sintetis yang diperkenalkan oleh (Bunkhumpornpat et al., 2009). Penerapan bagging pada safe-leve/SMOTE selanjutnya disebut sebagai safe-leve/SMOTEBagging dalam penelitian ini.

\subsection{Metode Penelitian}

Tahapan analisis yang dilakukan pada penelitian ini disajikan pada Gambar 1 sebagai berikut. 


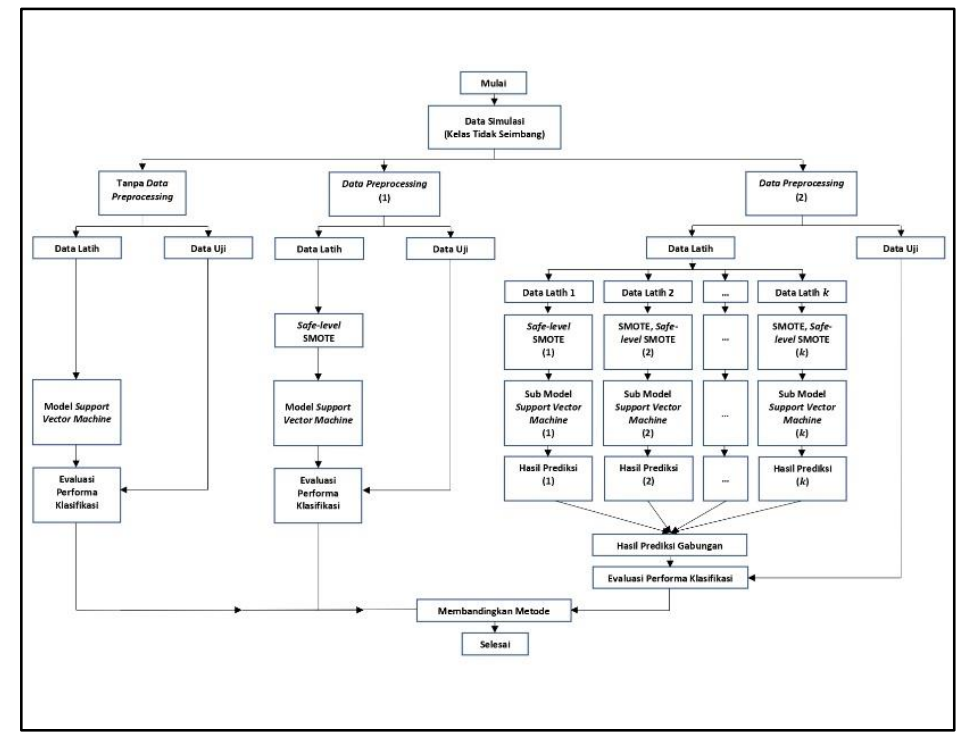

Gambar 1: Diagram alir penelitian

Alur penelitian yang disajikan pada Gambar 1 diterapkan bagi seluruh jenis data simulasi. Gugus data simulasi dibagi menjadi data latih (80 persen) dan data uji (20 persen). Terdapat tiga skema yang diberikan pada setiap data simulasi, yaitu tanpa tahap data preprocessing dan melalui tahap data preprocessing. Data preprocessing (1) menerapkan safe-level SMOTE, sedangkan data preprocessing (2) menerapkan safe-level SMOTEBagging. Kedua skema tersebut menghasilkan data latih baru yang memuat data sintetis sehingga menjadi lebih seimbang. Selanjutnya metode klasifikasi Support Vector Machine dengan kernel radial basis diterapkan pada semua jenis data latih. Pada skema yang melalui data preprocessing, hasil prediksi gabungan diperoleh dengan menggabungkan sebanyak $k$ buah prediksi untuk memperoleh prediksi akhir berdasarkan voting terbanyak sebagai berikut:

$$
H(x)=c_{j}, j i k a \sum_{i=1}^{T} h_{i}^{j}(x)>\frac{1}{2} \sum_{k=1}^{l} \sum_{i=1}^{T} h_{i}^{k}(x)
$$

dimana $c_{j}$ merupakan kelas, $h_{i}^{j}(x)$ adalah prediksi kelas dari $h_{i}$ untuk label kelas $c_{j}$, $h_{i}^{k}(x)$ adalah prediksi untuk semua kelas. $c_{j}$ adalah prediksi akhir jika vote yang dihasilkan lebih dari setengah vote semua kelas. Evaluasi performa metode klasifikasi dilakukan menggunakan data uji dengan melihat ukuran akurasi, sensitifitas, dan spesifisitas. Tahap akhir penelitian membandingkan kinerja metode klasifikasi Support Vector Machine pada data asli (tanpa data preprocessing) dan data yang diproses terlebih dahulu menggunakan safe-level SMOTE dan safe-level SMOTEBagging.

\section{Hasil dan Pembahasan}

\subsection{Deskripsi Data Simulasi}

Data peubah bebas dibangkitkan berdasarkan peubah acak normal ganda dan disimbolkan dengan $X_{1}$ dan $X_{2}$ menggunakan software $R$. Peubah tidak bebas bersifat kategorik dimana 0 merupakan amatan kelas mayoritas dan 1 untuk amatan kelas 
minoritas. Jumlah amatan seluruhnya adalah 1000 amatan sehingga banyaknya amatan bagi setiap data simulasi disajikan pada Tabel 3.

Tabel 3: Jumlah amatan kelas mayoritas dan minoritas

\begin{tabular}{ccc}
$\begin{array}{c}\text { Data } \\
\text { Simulasi }\end{array}$ & $\begin{array}{c}\text { Kelas Mayoritas } \\
(0)\end{array}$ & $\begin{array}{c}\text { Kelas Minoritas } \\
(1)\end{array}$ \\
\hline Data 1 & 950 & 50 \\
Data 2 & 900 & 100 \\
Data 3 & 850 & 150
\end{tabular}

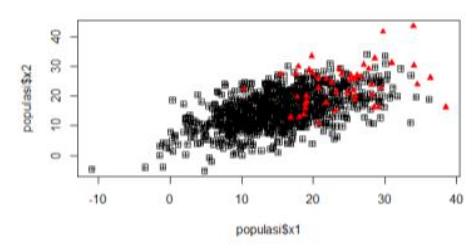

(a)

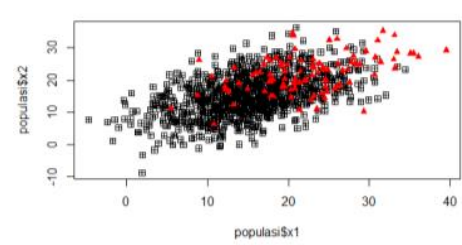

(b)

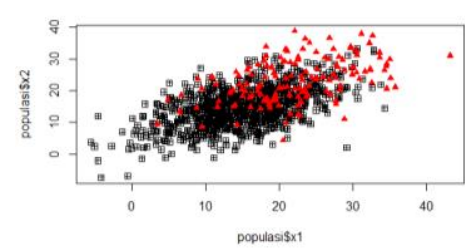

(c)

Gambar 2: Diagram pencar data simulasi dengan proporsi ketidakseimbangan:

(a) $95 \%: 5 \%$, (b) 90\%:10\%, dan (c) $85 \%: 15 \%$.

Penentuan letak amatan kelas mayoritas dan minoritas selanjutnya menjadi perhatian karena hal tersebut berkaitan dengan bagaimana algoritme safe-level SMOTE bekerja dalam membangkitkan data sintetis. Safe-level SMOTE akan membangkitkan data sintetis di wilayah yang aman. Dalam kondisi amatan kelas mayoritas dan minoritas berjauhan, maka safe-level SMOTE memiliki peluang lebih besar dalam membangkitkan data sintetis di wilayah yang berdekatan dengan amatan kelas minoritas lainnya. Hal tersebut berimplikasi pada minimnya kesalahan klasifikasi yang dihasilkan, dibandingkan dengan ketika posisi amatan dari kedua kelas saling berdekatan atau beririsan. Oleh karena itu, peubah bebas dibangkitkan sedemikian rupa agar memiliki sebaran kelas yang beririsan sebagaimana disajikan pada Gambar 2 untuk melihat kinerja dari safe-level SMOTE. Amatan berwarna hitam berasal dari kelas mayoritas, sedangkan amatan berwarna merah berasal dari kelas minoritas.

\subsection{Metode Klasifikasi Standar}

Metode klasifikasi Support Verctor Machine dengan kernel radial basis diterapkan pada setiap data simulasi dengan kondisi jumlah amatan pada kedua kelas kelas tidak seimbang. Penggunaan kernel dalam metode Support Vector Machine ini karena data simulasi yang terbentuk tidak dapat dipisahkan secara linier. Hasil kinerja model kasifikasi Support Verctor Machine disajikan pada Tabel 4.

Sensitifitas merupakan rasio hasil prediksi benar positif (dalam hal ini 0) dibandingkan dengan keseluruhan data yang benar positif (0). Sensitifitas dapat digunakan ketika kejadian yang diharapkan adalah lebih banyak false positive dibandingkan dengan false negative, artinya lebih banyak amatan kelas minoritas yang diklasifikasikan ke dalam kelas mayoritas dibandingkan dengan kelas mayoritas yang 
diklasifikasikan ke dalam kelas minoritas. Dalam kasus yang sangat serius, kesalahan dalam mengklasifikasikan amatan kelas minoritas ke dalam kelas mayoritas akan menimbulkan masalah yang sangat serius dan kerugian yang sangat besar.

Tabel 4: Kinerja SVM tanpa menyeimbangkan jumlah amatan kedua kelas (\%)

\begin{tabular}{cccc}
\hline Ukuran Kinerja & Data 1 & Data 2 & Data 3 \\
\hline Akurasi & 95,50 & 94,00 & 90,00 \\
Sensitifitas & 100,00 & 99,44 & 99,41 \\
Spesifisitas & 10,00 & 45,00 & 36,67 \\
\hline
\end{tabular}

Data 2 dan 3 juga masih memberikan nilai sensitifitas yang tinggi, yaitu 99,44 persen dan 99,41 persen. Secara umum seluruh data simulasi memberikan nilai sensitifas yang tinggi yang berarti bahwa Support Vector Machine mampu memberikan keakuratan dalam memprediksi kelas mayoritas. Hal sebaliknya ditunjukkan oleh ukuran spesifisitas. Spesifitas mengukur sebarapa akurat metode pengklasifikasi dalam memprediksi amatan kelas minoritas. Berdasarkan data uji, nilai spesifisitas bagi data 1 merupakan yang terendah yaitu hanya 10 persen, artinya hanya 10 persen amatan kelas minoritas yang benar diprediksi sebagai amatan kelas minoritas dibandingkan dengan keseluruhan amatan yang sesungguhnya berasal dari kelas minoritas. Data 2 dan 3 pun menunjukan nilai spesifisitas yang sangat rendah, walaupun lebih baik dibandingkan dengan data simulasi pertama. Berdasarkan data uji untuk data simulasi ke-2, lebih dari 50 persen amatan kelas minoritas diklasifikasikan sebagai amatan kelas mayoritas, dan 19 dari 30 amatan kelas minoritas pada data simulasi ke-3 diklasifikasikan sebagai kelas mayoritas. Hal ini menunjukan metode klasifikasi memberikan kinerja yang buruk dalam memprediksi amatan kelas minoritas ketika kondisi kelas tidak seimbang dibiarkan.

\subsection{Metode Klasifikasi dengan Penerapan Safe-level SMOTE}

Skema dengan penerapan safe-level SMOTE pada data latih memberikan kinerja metode klasifikasi seperti yang disajikan pada Tabel 5. Data latih yang sebelumnya memiliki kelas dengan jumlah amatan yang tidak seimbang akan ditambah jumlah amatan kelas minoritasnya sehingga memiliki data latih yang baru. Proses penambahan jumlah data buatan atau sintetis pada kelas minoritas untuk masingmasing data simulasi akan menghasilkan data latih baru dengan jumlah yang berbeda. Hal ini disebabkan karena proporsi ketidakseimbangan data awal serta jumlah data latih dan data uji yang bagi setiap data simulasi juga berbeda sehingga penambahan data buatannya yang dihasilkan juga berbeda. Pada tahap ini, jumlah tetangga terdekat yang dipilih adalah sebanyak 5 atau $k=5$.

Tabel 5: Kinerja SVM dengan menerapkan safe-level SMOTE (\%)

\begin{tabular}{cccc}
\hline Ukuran Kinerja & Data 1 & Data 2 & Data 3 \\
\hline Akurasi & 96,00 & 93,50 & 90,50 \\
Sensitifitas & 100,00 & 98,89 & 98,82 \\
Spesifisitas & 20,00 & 45,00 & 43,33 \\
\hline
\end{tabular}


Berdasarkan Tabel 5, metode Support Vector Machine cukup konsisten dalam memberikan akurasi terhadap ketiga data simulasi. Data 1 memiliki tingkat keakuratan yang lebih tinggi (96 persen) dibandingkan dengan data yang sebelumnya tidak seimbang. Hal yang sama juga terjadi bagi data 3 dimana tingkat keakuratan yang diperoleh sebesar 90,50 persen, sedangkan data 2 memiliki tingkat akurasi sebesar 93,50 persen. Ukuran kerja klasifikasi akurasi dan sensitifitas dapat dipertimbangkan pada tahap ini karena data latih telah diterapkan proses penyeimbangan data menggunakan safe-levelSMOTE. Kinerja Support Vector Machine dalam memprediksi amatan kelas mayoritas sangat baik. Tingkat sensitifitas metode klasifikasi bagi data 1 menunjukan keakuratan yang sempurna yaitu 100 persen, sedangkan bagi data 2 dan 3 adalah 98.89 persen dan 98.82 persen.

Berdasarkan data uji, tingkat spesifisitas bagi ketiga data simulasi masih sangat rendah. Data 1 memiliki tingkat spesifisitas sebesar 20 persen. Rendahnya nilai tersebut disebabkan karena 80 persen amatan yang sesungguhnya berasal dari kelas minoritas diklasifikasikan sebagai amatan kelas mayoritas. Data 2 memiliki tingkat spesifisitas yang sama dengan kondisi data awal dimana tidak diaplikasikannya safeleve/ SMOTE yaitu sebesar 45 persen. Tingkat spesifisitas yang diperoleh data 3 lebih tinggi dibandingkan sebelumnya yaitu sebesar 43,33 persen, tetapi hal tersebut masih menunjukan kemampuan metode klasifikasi dalam memprediksi amatan kelas minoritas masih rendah. Kondisi sebaran data yang beririsan antara kelas mayoritas dan minoritas kemungkinan besar menghasilkan data buatan yang masih sangat berdekatan dengan kelas mayoritas sehingga hasil klasifikasinya masih dimungkinan mengalami kesalahan.

\subsection{Metode Klasifikasi dengan Penerapan Bagging pada Safe-level SMOTE}

Tahap ini merupakan gabungan antara metode safe-level SMOTE dan bagging dimana proses bootstrap akan diterapkan pada setiap data latih yang dihasilkan oleh data simulasi. Proses bootstrap akan menghasilkan himpunan data latih baru yang akan digunakan untuk membuat model klasifikasi menggunakan Support Vector Machine. Kinerja metode Support Vector Machine pada tahap ini disajikan pada Tabel 6. Proses bootstrap dilakukan sebanyak 50 kali sehingga akan diperoleh hasil prediksi dengan jumlah yang sama yaitu sebanyak 50 data uji bagi setiap data simulasi.

Tabel 6: Kinerja SVM dengan menerapkan safe-level SMOTEBagging (\%)

\begin{tabular}{cccc}
\hline Ukuran Kinerja & Data 1 & Data 2 & Data 3 \\
\hline Akurasi & 96,46 & 93,30 & 93,22 \\
Sensitifitas & 100,00 & 100,00 & 99,26 \\
Spesifisitas & 77,93 & 78,46 & 85,69 \\
\hline
\end{tabular}

Kinerja metode klasifikasi yang diterapkan safe-level SMOTE menunjukan hasil yang baik. Akurasi bagi ketiga data simulasi masih menunjukan angka yang tinggi, yaitu 96,46 persen bagi data simulasi ke-1, 93,30 persen bagi data ke-2, dan 93,22 persen bagi data ke-3. Tingkat sensitifitas yang dihasilkan pun menunjukan angka yang tinggi bagi semua data simulasi. Data 1 dan 2 memiliki tingkat sensitifitas sebesar 100 persen yang berarti bahwa kemampuan metode klasifikasi dalam memprediksi 
amatan kelas mayoritas sudah sangat baik dan tidak terjadi kesalahan klasifikasi. Data 3 memberikan tingkat sensitifitas yang sedikit lebih rendah dibandingkan dengan Data 1 dan Data 2, akan tetapi nilai yang dihasilkan masih sangat baik dan mendekati 100 persen, yaitu sebesar 99,26 persen. Ukuran kinerja metode klasifikasi yang mengalami peningkatan signifikan adalah spesifisitas. Dengan penerapan safe-level SMOTEBagging, metode Support Vector Machine mampu mengklasifikasikan amatan kelas minoritas ke dalam kelas yang seharusnya dengan lebih baik. Tingkat spesifisitas bagi data 1 adalah sebesar 77,93 persen. Perbaikan tingkat spesifisitas juga ditunjukkan di data 2 dan 3 . Lebih dari 80 persen amatan kelas minoritas telah diklasifikasikan dengan benar pada data simulasi ke-2. Hal tersebut menghasilkan tingkat spesifisitas yang jauh lebih tinggi dibandingkan sebelumnya yaitu menjadi sebesar 78,46 persen. Tingkat spesifisitas yang tertinggi berasal dari data simulasi ke3 dimana jumlah amatan minoritasnya paling banyak. Pada data 3 juga ditemukan lebih dari 80 persen amatan kelas minoritas yang diklasifikasikan ke dalam kelas yang sesungguhnya sehingga menghasilkan tingkat spesifisitas yang tinggi, yaitu sebesar 85,69 persen.

\subsection{Perbandingan Kinerja Metode Klasifikasi}

Kondisi kelas tidak seimbang memberikan pengaruh kepada beberapa ukuran kinerja model klasifikasi. Nilai akurasi yang dihasilkan oleh semua data simulasi, baik tanpa penerapan safe-level SMOTE maupun safe-level SMOTEBagging, sangat tinggi. Apabila hasil ini dijadikan sebagai satu-satunya ukuran kinerja metode klasifikasi akan sangat membahayakan karena amatan kelas minoritas memberikan konstribusi yang sangat sedikit dalam perhitungan akurasi. Sensitifitas lebih fokus kepada hasil prediksi kelas mayoritas dimana cenderung lebih memilih salah dalam mengklasifikasikan amatan kelas minoritas ke dalam kelas mayoritas dibandingkan dengan sebaliknya. Spesifisitas lebih memilih terjadinya false negative dibandingkan false positive, akan tetapi dalam kondisi data tidak seimbang kesalahan dalam mengklasifikasikan amatan kelas minoritas menjadi kelas mayoritas dalam jumlah yang banyak akan berdampak pada pengambilan keputusan di berbagai bidang. Oleh karena itu, spesifisitas menjadi ukuran yang sangat penting dalam menentukan kinerja metode klasifikasi.

Tabel 7: Perbandingan ukuran kinerja klasifikasi (\%)

\begin{tabular}{lccccccccc}
\hline \multicolumn{1}{c}{ Metode } & \multicolumn{3}{c}{ Data 1 } & \multicolumn{4}{c}{ Data 2} & \multicolumn{4}{c}{ Data 3 } \\
& A & B & C & A & B & C & A & B & C \\
\hline $\begin{array}{l}\text { Tanpa safe-level } \\
\text { SMOTE }\end{array}$ & 95,50 & 100,00 & $\mathbf{1 0 , 0 0}$ & 94,00 & 99,44 & $\mathbf{4 5 , 0 0}$ & 90,00 & 99,41 & $\mathbf{3 6 , 6 7}$ \\
$\begin{array}{l}\text { Safe-level SMOTE } \\
\text { Safe-level }\end{array}$ & 96,00 & 100,00 & $\mathbf{2 0 , 0 0}$ & 93,50 & 98,89 & $\mathbf{4 5 , 0 0}$ & 90,50 & 98,82 & $\mathbf{4 3 , 3 3}$ \\
SMOTEBagging & 96,46 & 100,00 & $\mathbf{7 7 , 9 3}$ & 93,30 & 100,00 & $\mathbf{7 8 , 4 6}$ & 93,22 & 99,26 & $\mathbf{8 5 , 6 9}$ \\
\hline
\end{tabular}

Keterangan: $\mathrm{A}=$ akurasi, $\mathrm{B}=$ sensitifitas, $\mathrm{C}=$ spesifisitas .

Tabel 7 menunjukan keseluruhan hasil yang dilakukan pada penelitian ini. Secara umum, nilai akurasi dan sensitifitas pada seluruh data simulasi di ketiga kondisi, yaitu tanpa penerapan safe-level SMOTE, adanya penerapan safe-level SMOTE dan safelevel SMOTEBagging, yang dihasilkan oleh metode Support Vector Machine tidak 
mengalami perubahan yang signifikan. Keduanya bernilai sangat tinggi karena jumlah amatan kelas mayoritas memiliki kontribusi yang sangat besar di dalamnya. Oleh karena itu, satu-satunya ukuran yang dapat dijadikan sebagai pembanding adalah spesifisitas.

Gambar 3 menunjukan bahwa ketika metode klasifikasi langsung diterapkan pada data dengan kelas tidak seimbang, maka nilai spesifisitas yang dihasilkan dari data uji sangat rendah. Tingkat spesifisitas mengalami kenaikan ketika safe-level SMOTE mulai diterapkan ke dalam data latih, artinya kedua kelas akan memiliki jumlah amatan yang lebih seimbang. Kenaikan spesifisitas sebesar 10 persen terjadi di data 1 dan 6,67 persen terjadi pada data 3 ketika safe-level SMOTE diterapkan, sedangkan spesifisitas di data 2 tidak mengalami perubahan.

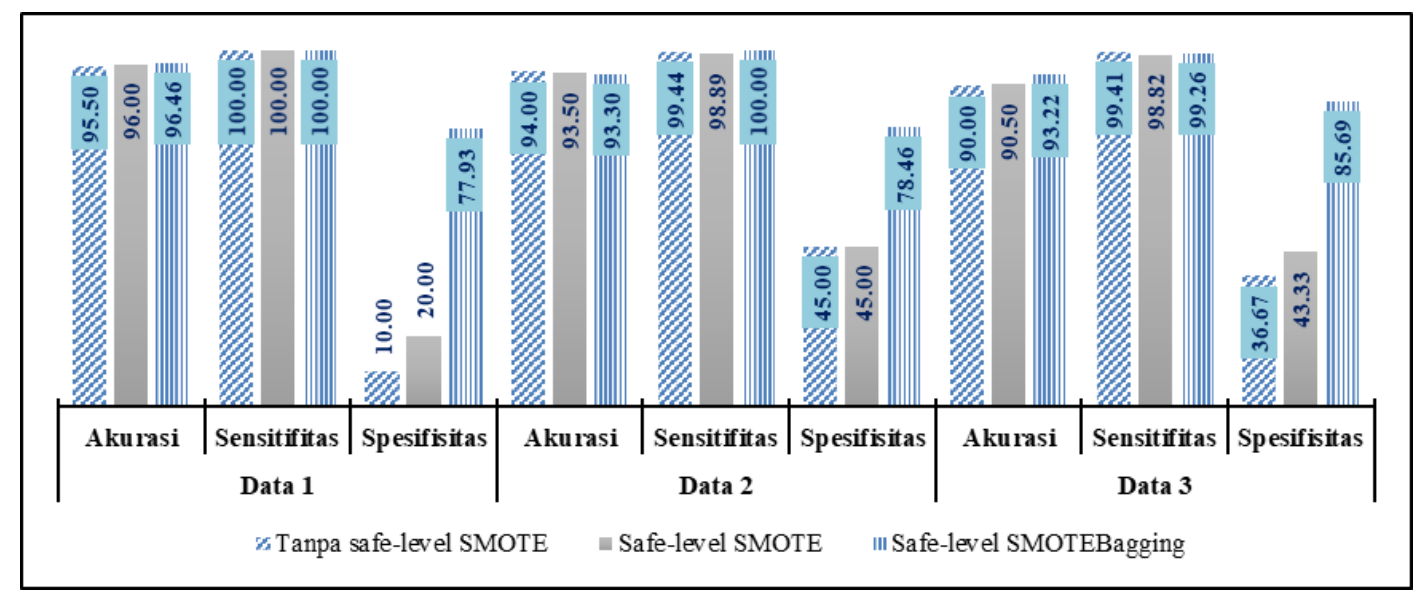

Gambar 3: Perbandingan performa Support Vector Machine

Penerapan metode safe-level SMOTEBagging berhasil memperbaiki kinerja metode klasifikasi Support Vector Machine. Hal ini dapat terlihat dari besarnya peningkatan spesifisitas yang terjadi pada semua data simulasi. Tingkat spesifisitas yang diperoleh ketika bagging diterapkan untuk setiap data simulasi adalah 77,93 persen bagi data 1, 78,46 persen bagi data 2, dan 85,69 persen bagi data 3 . Peningkatan terbesar terjadi pada data 1 (57,93 persen) dimana proporsi kelas minoritasnya paling kecil, sedangkan peningkatan yang diperoleh dari skema penerapan safe-level SMOTE tanpa bagging bagi data simulasi 2 dan 3 secara berturut-turut adalah 33,46 persen dan 42,36 persen. Hasil ini menunjukan bahwa majority voting yang dilakukan pada proses bootstrap dan aggregating membuat kinerja Support Vector Machine jauh lebih baik dibandingkan dengan sebelumnya.

\section{Simpulan dan Saran}

Spesifisitas menjadi ukuran yang diutamakan dalam menentukan kinerja metode klasifikasi karena mampu mengukur tingkat keakuratan dalam memprediksi kelas minoritas yang menjadi perhatian. Metode Support Vector Machine yang diterapkan pada data latih yang tidak mendapatkan penanganan kelas tidak seimbang memiliki tingkat keakuratan dan sensitifitas yang tinggi bagi ketiga jenis data simulasi, namun memberikan tingkat spesifisitas yang sangat rendah. Spesifisitas semakin meningkat ketika jumlah amatan kedua kelas mulai seimbang akibat diterapkannya safe-level 
SMOTE. Kinerja metode Support Vector Machine yang paling baik dalam memprediksi amatan kelas minoritas ditunjukkan ketika data latih dari setiap data simulasi diterapkan boostrap dan aggregating (Bagging). Hasil yang diperoleh tersebut konsisten bagi seluruh data simulasi dimana sebaran data antara kedua kelas saling beririsan.

Pengembangan yang dapat dilakukan dari penelitian ini adalah dengan mengkaji metode safe-levelSMOTEBagging pada data real sehingga teruji konsistensi performanya. Selain itu, variabel yang akan dilibatkan memiliki skala pengukuran yang berbeda sehingga metode klasifikasi yang diterapkan juga lebih bervariasi. Dengan begitu diharapkan kajian dalam penanganan kelas tidak seimbang akan semakin komprehensif.

Ucapan Terima Kasih. Terima kasih kepada Fakultas Matematika dan IImu Pengetahuan Alam Universitas Negeri Jakarta yang telah memberikan dukungan dalam penelitian ini.

\section{Daftar Pustaka}

Aggarwa, C. C. (2015). Data Classification: Algorithms and Applications. Chapman \& Hall/CRC Data Mining and Knowledge Discovery Series.

Akbani, R., Kwek, S., \& Japkowicz, N. (2004). Applying support vector machines to imbalanced datasets. European Conference on Machine Learning, 39-50. Springer.

Bunkhumpornpat, C., Sinapiromsaran, K., \& Lursinsap, C. (2009). Safe-level-smote: Safe-level-synthetic minority over-sampling technique for handling the class imbalanced problem. Pacific-Asia Conference on Knowledge Discovery and Data Mining, 475-482. Springer.

Chawla, N. V. (2009). Data mining for imbalanced datasets: An overview. Data Mining and Knowledge Discovery Handbook, 875-886.

Chawla, N. V., Bowyer, K. W., Hall, L. O., \& Kegelmeyer, W. P. (2002). SMOTE: synthetic minority over-sampling technique. Journal of Artificial Intelligence Research, 16: 321-357.

Han, H., Wang, W.-Y., \& Mao, B.-H. (2005). Borderline-SMOTE: a new over-sampling method in imbalanced data sets learning. International Conference on Intelligent Computing, 878-887. Springer.

Hanifah, F. S., Wijayanto, H., \& Kurnia, A. (2015). Smotebagging algorithm for imbalanced dataset in logistic regression analysis (case: Credit of bank $\mathrm{x}$ ). Applied Mathematical Sciences, 9(138): 6857-6865.

He, H., \& Garcia, E. A. (2009). Learning from imbalanced data. IEEE Transactions on Knowledge and Data Engineering, 21(9): 1263-1284.

Hussein, A. S., Li, T., Yohannese, C. W., \& Bashir, K. (2019). A-SMOTE: A new preprocessing approach for highly imbalanced datasets by improving SMOTE. International Journal of Computational Intelligence Systems, 12(2): 1412-1422. 
Japkowicz, N. (2000). Learning from imbalanced data sets: a comparison of various strategies. AAAI Workshop on Learning from Imbalanced Data Sets, 68:10-15. AAAI Press Menlo Park, CA.

Mahdizadeh, M., \& Eftekhari, M. (2013). Designing fuzzy imbalanced classifier based on the subtractive clustering and genetic programming. 2013 13th Iranian Conference on Fuzzy Systems (IFSC), 1-6. IEEE.

Sahare, M., \& Gupta, H. (2012). A review of multi-class classification for imbalanced data. International Journal of Advanced Computer Research, 2(3): 160-164.

Sartono, B., \& Syafitri, U. D. (2010). Metode pohon gabungan: Solusi pilihan untuk mengatasi kelemahan pohon regresi dan klasifikasi tunggal. Forum Statistika Dan Komputasi, 15(1): 1-7.

Zhou, Z.-H. (2012). Ensemble methods: foundations and algorithms. CRC press. 